\title{
Mystery of Unicellular and Multicellular Keratinous Tubercles of the Epidermal or Dermal Origin in Fish
}

\author{
Pinky Tripathi* \\ Sri Agrasen Kanya PG College, India
}

Submission: December 22, 2017; Published: April 09, 2018

*Corresponding author: Pinky Tripathi, Sri Agrasen Kanya PG College, Bulanala, Varanasi-221002, India, Email: pinkysatsangi02@gmail.com

\begin{abstract}
Multicellular keratinous tubercles in the form of breeding tubercles (BTs) under a perplex variety of other terms have long been known in the Ichthyology write-ups. These tubercles in fish are most often found on the head, rostral cap or snout, around the eyes, operculum, on the rays of the pectoral fins, pelvic fins, and even they are arranged in fine patterns on scales usually be confused with unicellular and multicellular non-BTs as there is no much variation in the appearance of BTs and non-BTs morphology. Variety of non-BTs have different purposes like minute tubercles may even used for observations of larval development in some fish and most commonly the tubercles which are non-breeding help to understand the functional significance in relation to mechanical protection, friction and adhesion.

There is absence of very clear evidence about the exact biological and evolutionary significance of BTs, however, there are many possibilities. They may be significant for protection against injury, weapons in intense pre-spawning behaviour or stimulators during spawning, an indicator of health or dominance. In consequence, the actual purpose of BTs could be some, or all, of the above things. The review will make systematists, ethologists, other zoologists and researchers more aware to look for the structures with clear concept of differentiation in between BTs and nonBTs so as to use them in understanding the adaptation, behaviour and evolution of fishes.

Keywords : Contact organs; Epidermal appendages; Fish skin roughness; keratinised skin nodules; Minute tubercles; Nuptial tubercles; Pearl organs
\end{abstract}

Abbreviations : BTs: Breeding Tubercles; LM: Light Microscope; SEM: Scanning Electron Microscope

\section{Introduction}

Sykes [1] was one of the first workers to describe and figure tubercles on Indian minnows in five new species that he placed in Cyprinus, Varicorhinus, and Barbus. Leydig [2] figured the tubercles of Cyprinus carpio, Rhodeus amarus (without a keratinized cap), and Discognathus (=Garra) lamta. Fowler [3] and Denoncourt [4], among others, examined tubercle distribution [5]. Branson [6] and Wiley \& Collette [7] described tubercle anatomy. Wiley \& Collette [7] used differences in tubercle distribution and structure to support evidence for phylogenetic relationships among ordinal groups of cyprinids.

The literature review of the occurrence of breeding tubercles and contact organs was begun by Collette [8]. In 1969, Wiley compared the morphology and histology of the tubercles and contact organs of representative fishes in an attempt to devise a meaningful nomenclature for the nuptial structures. Here efforts are made to elucidate not all of the references on tubercles and contact organs but to include those most important ones which are biologically and historically significant. Roberts [9] described horny projections arising from single epidermal cells as unculi; Egami \& Nambu [10] stated that innervations of fin rays bearing tubercles of male Oryzias latipes was greater than that in fin rays of females, which lack tubercles. However, horny projections arising from multicellular cells, or tubercles, of most teleosts are described and discussed regarding their status as many indicators with special representative stimuli. The well-known multicellular horny tubercles, especially prominent features of portions of the epidermis are present on some species in at least fifteen families of fishes in four orders:

1. Salmoniformes, suborder Salmonoidei (Salmonidae, Plecoglossidae, and Osmeridae) and suborder Galaxioidei (Retropinnidae)

2. Gonorynchiformes, suborder Chanoidei (Kneriidae, Phractolaemidae)

3. Cypriniformes, suborder Characoidei (Lebiasinidae and Parodontidae), and suborder Cyprinoidei (Cyprinidae, Gyrinocheilidae, Psilorhynchidae, Catostomidae, Homalopteridae, Cobitidae)

4. Perciformes, suborder Percoidei (Percidae), [7] but have not been found in any non-ostariophysan fishes [9]. 
Superficially similar structures that are not sexually dimorphic have also been reported in an African family of freshwater catfishes (Siluriformes, Mochokidae). Analogous dermal structures, known as contact organs, are present on the scales or fin rays of nine families in three orders:

a. Atheriniformes, suborders Exocoetoidei (Belonidae) and Cyprinodontoidei (Oryziatidae, Cyprinodontidae, Anablepidae, and Poecliidae);

b. Cypriniformes, suborder Characoidei (Characidae and Gasteropelecidae)

c. Scorpaeniformes (Cottidae and Cottocomephoridae), [7].

In addition to BTs, the various useful terms have been given by Scientists such as in the form of "Contact organ" for the dermal structures defined by Newman [11], "Small nodules" by Stokell [12], "Pearl organs" by Reighard [13]; Norman [14]; Jakubowski et al. [15]; "Hook shaped tubercles" by Bell-Cross \& Jubb [16], "Keratinised epidermal appendages" by Fischer et al. [17], "Spike-like keratinized epidermal structures by McMillan et al. [18]. In 1970, Wiley and Collette described three different kinds of BTs. The $1^{\text {st }}$ is composed of not obviously keratinised epidermal cells. In the $2^{\text {nd }}$ type a hard conical keratinised epidermal cap is formed which resembles a plant thorn. The $3^{\text {rd }}$ type of tubercle is the contact organ which, although similar in function, is quite different and is formed of calcified dermal outgrowths from scales or fin rays. The conical epidermal cap like $2^{\text {nd }}$ type of BTs is most significant, here the cells become flattened as they are keratinised and finally die, and the nuclei are either lost or become parakeratotically shrunken. Evidence for keratinisation comes from histological appearance and various staining reactions to detect bound cysteine and bound phospholipids.

Spearman [19] reported that cornification or keratinisation is uncommon in fish and occurs only in restricted sites like in breeding or nuptial tubercles to maintain close contact during spawning and probably around the sharp jaws in herbivorous fish. On the basis of literatures on skin based on morphological studies in several fish species such as, keratinocytes remain metabolically active throughout, including the outermost layer, and lack morphological signs of cornification, in contrast to the organization of BTs, contact organs on the head and pectoral fin rays, described as keratinized epidermal appendages covered by a layer of dead cells with altered content, suggesting that in BTs, keratinocytes might undergo more advanced, cornification-like differentiation processes [14].

\section{Non-BTs}

Non-BTs were also mentioned in old literatures with various poorly descriptive, unspecific, or anatomically inappropriate terms. In1841, Sykes reported "Spines" projecting from rostral cap, lips, and tubercles (non-breeding) on mental adhesive disc.
Afterwards in 1901, Boulenger reported Horny projections from single cells "Hornzahnchen" on rostral cap and mental adhesive organ and in 1921, Hora observed "Minute spines" on tubercles (non-breeding) of rostral cap and mental adhesive disc. The term "minute tubercles" defined by Suzuki \& Hibiya [20,21], Suzuki et al. [22] on the skin surface of fish larvae. Singh et al. [23] reported the anterior region of the upper lip in Hill-stream fish Schizothorax richardsonii (Cypriniformes: Cyprinidae) have much small and large number of tubercles (non-breeding) with different shape and size such as spherical, cylindrical and elongated, each tubercle bears numerous glandular secretive device and possibly keratinized spine, help in adhesion due to friction between tubercles and surface of substratum making a firm hold in rapidly flowing waters.

Fish have a wide range of protective skin adaptations, which enable them to occupy habitats ranging from rocky bottom surface to turbulent water. The skin of general body, head and snout is usually scale less and the epidermis is of both types i.e. keratinized as well as mucogenic. The rough epidermis of snout bears only epithelial cells. Surface of these epithelial cells are modified into epidermal growth the unculi. These unculi are short and stumpy structures. In these fish, the epidermis of middorsal part of snout possesses epidermal tubercles. These type of structures are absent in dorso-lateral part of general body and snout epidermis [18]. Hora [15] also suggested that the so-called anterior labial fold in Garra species is fringed and tuberculate and helps the fish adhere to rocks.

According to Roberts [24], unculi are related morphologically to the relatively well-known multi-cellular horny tubercles (including BTs) of Ostariophysi and other fishes but differ from them in anatomical distribution and function.

Singh et al. [23] studied on a hill stream fish Schizothorax richardsonii belongs to the family Cyprinidae and is predominantly adapted to life in swift flowing waters. The anterior region of the upper lip had much small and large number of tubercles (non-breeding) with different shape and size such as spherical, cylindrical and elongated. Such as the callus part drawn and a cavity was produced that surrounded by the tuberculated borders. The lower lip on its ventral side was associated with a specialized structure the tuberculated adhesive pad through a thin fold of skin. These non-BTs were responsible for adhesion, resulted due to friction between tubercles and surface of substratum.

\section{BTs}

Nuptial tubercles may be grouped into three general categories on the basis of their structure:

1. Tubercles consisting of aggregations of non-keratinized epidermal cells (if keratinization is present, it is confined to the most superficial layers of cells and may form a light cuticle). 
2. Tubercles containing substantial numbers of fully keratinized cells that are organized to form a discrete, usually conical cap, a major component of the tubercle.

3. Contact organs (a term proposed by [27]) composed of dermal bony outgrowths or spicules projecting from a fin ray or scale margin and surrounded by the epidermis, through which the bony outgrowths may protrude.

Cornification observed on the unculiferous multicellular BTs in a small number of cyprinoids and siluroids [7]. In histological sections of tubercles prepared with Mallory's Triple Stain, the unculi are orange-red, a staining reaction presumably due to keratin (Our personal observations). In our lab during my doctoral studies, we observed BTs towards head region on rostral cap and operculum in one of the six fish species that is a hill stream fish Garra lamta, Its histological and histochemical properties were same as keratinised region of rostral cap (Pinky et al. 2004) but the BTs vary in appearance, projecting out from epithelial surface so as to look cone like V-shaped outgrowth with light microscope (unpublished data).

All or most species of family Cyprinidae develop multicellular horny tubercles or BTs on the head and other parts of the body and a few develop enormous rostral projections heavily set with large, bifid or trifid tubercles. The most heavily tuberculate individuals tend to be sexually mature females [27,24]. Roberts [24] had various family observations on BTs such as Gyrinocheilidae is rheophilic bottom-dwelling family, adults of genus Gyrinocheilus develop multicellular BTs on the snout and head which are sometimes better developed in females than in males; Catostomidae is predominantly bottom-dwelling cyprinoid family comprises large BTs on the head, body, and fins of sexually mature adults; small multicellular BTs occur on the head and on the dorsal surface of the pectoral fin in Psilorhynchus sucatio and P. balitora; mature males of genus Barilius, family Cyprinidae also exhibit extensive development of multicellular BTs on the head, spawning behaviour of Barilius bendelisis is unknown. Roberts predicted that it involves substrate contact by the unculiferous prepectoral groove and horny tubercles on the gular region of the male; Cobitididae is the predominantly Asian cyprinoid bottom-dwelling family in which the outermost branched pectoral fin-ray is greatly enlarged or thickened, and its dorsal surface may bear horny BTs. BTs are restricted to fishes belonging to the cohort Euteleostei. To explain their presence, we must consider what the fishes with them have in common. First, fishes that have breeding tubercles, or the species within a group that have them, are fresh-water or inshore marine inhabitants. The analogous dermal contact organs present in the Cyprinodontoidei, Characidae, and Cottidae are also developed in fresh-water and inshore marine species. No pelagic or epipelagic marine fishes are known to develop the tubercles. Secondly, most families with these tubercles belong to groups of fishes with cycloid scales. Only few families (Percidae, Cottidae, and Cottocomephoridae) belong to the great group of higher fishes-the Acanthopterygii- which usually have ctenoid scales [7].

\section{Histology of BTs}

The multicellular keratinized epithelia are mainly composed of the epithelial cells. The lymphocytes are infrequent and could be located on careful search, confined in the intercellular spaces in between the basal cells. The gland cells and the taste buds usually occur in the mucogenic epithelia are absent. Epidermal cells are produced by mitoses in a columnar to cuboidal stratum germinativum next to the basement membrane. The cells in more superficial layers hypertrophy and become polygonal. They are characterized by large vesicular nuclei with one or more prominent nucleoli and often granular, acidophilic cytoplasm. Well-developed intercellular spaces and many intercellular bridges usually lie between the hypertrophied cells. The transition between hypertrophied cells and the keratinized layer is so abrupt that transitional stage is rarely observed. During keratinization, the nuclei disappear or persist as pyknotic remnants in the usually flattened, irregular cells of the keratinized layer. The keratin becomes light orange to red, in Mallory's triple stain. In a typical preparation, undifferentiated epidermal cells of the germinal layer have light blue cytoplasm that becomes darker blue as cells hypertrophy and accumulate prekeratin granules, and violet in the largest cells before keratinization. The nuclei of hypertrophied cells contain prominent, darkly stained nucleoli.

Wiley \& Collette [7] reported two species, Moxostoma erythrurum and Erimyzon sucetta, both are distinctly different from each other in tubercle morphology. The tubercles of $M$. erythrurum were simply mounds of cells formed by epithelial hypertrophy and hyperplasia with keratinization of the tissue above a plane parallel to the surface. In contrast, the snout tubercle of E. sucetta was a solid keratinized cone supported by vascularized hypertrophied epithelium and closely resembles some of the larger cyprinid tubercles. Many of the larger cyprinid tubercles develop vascularised dermal papillae which extend into the hypertrophied epithelium of the tubercle core, while, in some tubercles, the dermal papillae are accompanied by a layer of the stratum germinativum and probably serve the dual function of providing nutrition to the rapidly growing epidermal cells of the tubercle and increasing the number of germinative cells required for the rapid growth that is characteristic of developing tubercles Fischer et al. [17] identified the zebrafish BTs as sites with higher keratinocyte proliferation in basal layers as well as more advanced, cornification-like keratinocyte differentiation in upper layers, including transglutaminase expression and stronger keratinization, exclusive presence of tight junctions in second-tier keratinocytes, and rudimentary lipid envelope formation and constant desquamation and renewal of surface keratinocytes. 


\section{Histochemistry of BTs}

In the older literature, however, the unculi, in general, are described as cornified or horny without any histochemical characterisation. Strong eosinophilia with Papanicolaou stain and strong fluorescence with the different fluorochromes, with or without prior DNase/RNase treatment further confirms the keratinized nature of the BTs in Garra lamta. (Personal observations). Cysteine bound $-\mathrm{SH}$ groups elaborated by the epithelial cells during keratinization gradually increase in concentration in the cells towards the surface. These, in the major portions of the unculi, do not seem to be strongly converted into cystine bound -SS groups at the thin peripheral regions of the unculi [28] and cone like projections of BTs (unpublished data) in Garra lamta. The absence of cystine bound -SS groups, which are reported to hold together adjacent keratin side chains (Alexander et al., 1963), indicates that keratin in the BTs in Garra lamta is not so strongly bonded. Schwerdtferger \& Bereiter-Hahn [29] reported the presence of cystine bound -SS groups in addition to cysteine bound -SH groups in the pearl organs (=BTs) of Abramis brama, Rutilus rutilus. Presence of GPs with oxidizable vicinal diols in the BTs (personal observation), suggests further studies, necessary to understand its role in relation to keratinization in BTs of fish. The GPs synthesised in the epithelial cells are secreted at the surface forming an extracellular coat. It varies considerably in thickness and consistency in different groups of fishes. It is thick and even appears fibrous on epidermal tubercles of Agonus cataphractus Whitear \& Mittal (25).

\section{Discussion}

Leydig [2] remarked on the similarities in morphology and development of tubercles, mammalian hair, saurian femoral pores, and skin sense organs. Newman [26] long ago suggested, ctenoid scales may have evolved in higher fishes to replace permanently the temporary contact organs and BTs found during the breeding season in lower fishes. The BTs, or pearl organs, presumed to be secondary sexual structures are composed of substantial amounts of keratin. They are common in several families of cypriniform fishes and they are also known in a few gonorynchiform and salmonoid fishes. The correlation between contact organ location and behaviour suggests that they may be tactile, enabling the male to determine his exact position relative to the female [30]. Wiley \& Collette [7] and Collette [31] discussed the reproductive role of multicellular horny tubercles (BTs) of fishes. In many species the head and especially the snout are heavily tuberculate, and this does not appear to be sexually dimorphic: the tubercles are already well developed in very small juveniles and are equally well developed in large mature specimens of both sexes [24].

Initially there was little evidence to support the suggestion made by Reighard [32-34] that tubercles protect body and fin surfaces in nest building. However, later on after seveneight decades, suggested roles of BTs include defence against mechanical injury, microorganisms and parasites, protection of nests and territories [35-38]. Branson [6] suggested that tubercles also function in holding to the substrate during oviposition or in tending the nest and eggs or that made by Branson [39] that anterior head tubercles are used for scooping.

The importance of epidermal cornification in the evolution of tetrapod vertebrates is common knowledge. The diversity of terrestrial vertebrate life as we know it would be impossible without the "boundary layer" of cornified epidermis, so vital for maintenance of the internal milieu. If the presence of horny teeth on the mouth parts of both living groups of primitive jawless fishes or Agnatha can be taken as an indication, then horny structures may have played a significant role in the evolution of early vertebrates before true teeth evolved [24].

Males and females of Kneria develop numerous small multicellular horny tubercles on the dorsal and lateral surface of the head and body, but tubercles are absent on the paired fins. Phractolaemidae family comprises a single species, air-breathing Phractolaemus ansorgei. Sexually mature males bear large, spike-like horny tubercles immediately beneath the minute eyes and on the caudal peduncle, rows of microbranchiospines or unicellular tubercles on the gill rakers which may or may not be BTs [40]. BTs occur in many higher taxa of generic or family level for which no behavioural observations are available. Numerous well-developed multicellular horny tubercles observed in both sexes in Homalopteridae and Labeo long before they are capable of breeding, and that in catfishes these tubercles have not been linked to breeding behaviour [24].

According to [41], structures resembling unculi were found when using SEM, but not with LM studies. The unculus-like structures (seen with SEM) were identified with LM as either nucleate squamate surface epidermal cells or neuromasts. However, during my doctoral studies on many fish species we only observed BTs on rostral cap and operculum of Garra lamta towards head region with LM in histological sections only (unpublished data). The tubercles are keratin based nodules which are induced by male androgens and detach shortly after spawning $[7,37]$. The positive relationship between testosterone, elaborate breeding tubercle ornamentation and papillomatosis was demonstrated by Kortet et al. [37].

In Kortet et al. [38]. found that the BTs of the Roach (Rutilus rutilus) serve as a status badge, with more dominant males possessing more tubercles than less dominant males. It was also found that the tubercles serve as an indicator of male quality, meaning that males with more tubercles have greater reproductive success and are healthier (have fewer parasites). This means that the BTs serve as a marker to help the female fish pick mates that are healthier and have a better chance at fertilizing their eggs during a spawn.

Fischer et al. [17] identified the zebrafish BTs, epidermal appendages as specific epidermal structures and unravel essential roles of transcription factors TAp63 and p53 to 
promote both keratinocyte proliferation and their terminal differentiation by promoting Notch signalling and caspase 3 activity, ensured formation and proper homeostasis of the self-renewing stratified epithelium. Further they observed that Regular epidermis and BTs display different patterns of superficial cell renewal. BTs are formed during metamorphosis and undergo regular desquamation and renewal of superficial layers, however, BTs of adult zebrafish display more advanced stratification and keratinocyte differentiation. Epidermal tubercles are usually sex-limited to males or are better developed in males. They form during the breeding season and are afterwards moulted. McMillan et al. [18] reported that BTs are sexually dimorphic structures found in clusters on the dorsal surface of the anterior rays of zebrafish male pectoral fins, appear during sexual maturation and are maintained through regular shedding and renewal of the keratinized surface. They analysed that androgens induce and estrogens inhibit BT cluster formation [42].

\section{Conclusion}

This study provides new insight after the evaluation of review on tubercles mystery. Finally, it is concluded that the non-BTs which have no any relation with breeding and on the other hand BTs which are directly or indirectly anyhow related to breeding or spawning, often confused macroscopically with each other. On the basis of BTs morphology there are two general decisive remarks, first it is of great value to the distinguishing non-BTs and its various morphological status as a key adaptive features. Secondarily the BTs morphology has potential use as a character in studies of systematic and phylogenetic relationships in fish. After these two general concluding remarks, there is an extensive description offered, as some fish have tubercles and some do not is still questioned that is why experimental studies are needed to investigate the relation between presence and absence of BTs.

\section{References}

1. Sykes WH (1841) On the fishes of the Dukhun. Trans Zool Soc London 2: $349-378$.

2. Leydig F (1895) Integument und Hautsinnesorgane der Knochenfishc. Zool Jb Anat 8: 1-152.

3. Fowler HW (1912) Some features of ornamentation in fresh water fishes. The American Naturalist 46(548): 470-476.

4. Denoncourt RF (1969) Fishes that grow horns. The Conservationist, Newark 2: 30-31.

5. Huntsman, Gene R (1967) Nuptial tubercles in carpsuckers (Carpiodes). Copeia 2: 457-458.

6. Branson BA (1962) Observations on the breeding tubercles of some Ozarkian minnows with notes on the barbels of Hybopsis. Copeia 3: 532-539.

7. Wiley ML, Collette BB (1970) Breeding tubercles and contact organs in fishes: their occurrence, structure, and significance. Bull Am Mus Nat Hist 143: 143-216.

8. Collette BB (1965) Systematic significance of breeding tubercles in fishes of the family Percidae. Proc US Natl Mus 117 (3518): 567-614.
9. Roberts TR (1982) Unculi (Horny projections arising from single cells), an adaptive feature of the epidermis of Ostariophysan fishes. Zoologica Scripta 11: 55-76.

10. Egami N, Nambu M (1961) Factors initiating mating behavior and oviposition in the fish, Oryzias latipes. Jour Fac Sci Univ, Tokyo, Japan $9(2): 263-278$.

11. Newman HH (1907) Spawning behavior and sexual dimorphism in Fundulus heteroclitus and allied fish. Biol Bull (Woods Hole) 12(5): 314-348.

12. Stokell G (1941) A revision of the genus Retropinna. Rec Canterbury Mus 4(7): 361-372

13. Reighard J (1903) The function of the pearl organs of the Cyprinidae. Science new ser 17: 531.

14.Norman HS (1953) Pearl organs of the cyprinidae Proceedings of the Pennsylvania Academy of Science 27: 221-224.

15. Jakubowski, Michal, Ota Oliva (1967) Note on pearl organs of the stone loach, Noemacheilus barbatulus (Linnaeus, 1758) (Osteichthys, Cobitidae). Vestnik Ceskoslovenske Spol Zool 31(1): 25-27.

16. Bell-Cross G, Jubb RA (1973) The Amphiliidae of southern Africa and record of Amphilius lampei Piepschmann, from the Inyanga Mountains. Rhodesia Arnoldia 6: 1-9.

17. Fischer B, Metzger M, Richardson R, Knyphausen P, Ramezani T, et al. (2014) P53 and TAp63 Promote keratinocyte proliferation and differentiation in breeding tubercles of the zebrafish. PLoS Genet 10: e1004048.

18. McMillan SC, Geraudie J, Akimenko MA (2015) Pectoral Fin Breeding Tubercle Clusters: A Method to Determine Zebrafish Sex. Zebrafish 12(1): 121-123.

19. Spearman RIC (1973) The Integument. Cambridge University press, UK, England.

20.Suzuki N, Hibiya T (1984) Minute tubercles on the skin surface of larvae of Rhodeus (Cyprinidae). Japan J Ichthyol 31: 198-208.

21.Suzuki N, Hibiya T (1985) Minute tubercles on the skin surface of larvae of Acheilognathus and Pseudoperilampus (Cyprinidae). Japan J Ichthyol 32: 335-344.

22.Suzuki N, Oke A, Sugoh Y, Yamakawa K, Hibiya T, et al. (1986) Development of the bitterling, Tanakia lanago (Cyprinidae), with a note on minute tubercles on the skin surface. Japan J Ichthyol 33: 225231.

23. Singh H, Joshi SC, Bisht I, Agarwal SK (2013) Adaptive modification of lip and its associated structures of Hill-stream fish Schizothorax richardsonii (Cypriniformes: Cyprinidae). IOSR-JPBS 5(4): 59-65.

24. Roberts TR (1982) Unculi (Horny projections arising from single cells), an adaptive feature of the epidermis of Ostariophysan fishes. Zoologica Scripta 11: 55-76.

25. Whitear, M. \& Mittal, A. K. (1986). Structure of the skin of Agonus cataphractus (Teleostei). J. Zool., Lond. 210: 551-574.

26. Newman HH (1907) Spawning behavior and sexual dimorphism in Fundulus heteroclitus and allied fish. Biol Bull (Woods Hole) 12(5): 314-348.

27. Rauther M (1928) Der Saugmund von Discognuthus.-Zool. Jb Physiol 45: 45-76.

28. Pinky Mittal, Yashpal S, Ojha MJ, Mittal AK (2004) Occurrence of keratinization in the structures associated with lips of a hill stream fish Garra lamta (Hamilton) (Cyprinidae, Cypriniformes). J Fish Biol 65: 1165-1172.

29. Schwerdtfeger WK, Bereiter-Hahn J (1978) Histologische Untersuchungen der keratinisierung im laichausschlag von cypriniden (Teleostei, Pisces) Zool Anz 200: 95-113. 
30. Foster, Neal R (1967) Trends in the evolution of reproductive behavior in killifishes. Studies Trop Oceanogr 5: 549-566.

31. Collette BB (1965) Systematic significance of breeding tubercles in fishes of the family Percidae. Proc US Natl Mus 117 (3518): 567-614.

32. Reighard J (1903) The function of the pearl organs of the Cyprinidae. Science new ser 17: 531.

33. Reighard J (1904) Further observations on the breeding habits and on the function of the pearl organs in several species of Eventognathi. Ibid 19: 211-212.

34. Reighard J (1910) The pearl organs of American minnows in their relation to the factors of descent. Ibid 31: 472.

35. Ahnelt H, Keckeis H (1994) Breeding tubercles and spawning behaviour in Chondrostoma nasus (Teleostei: Cyprinidae): A correlation. Ichthyol Explor Freshwater 5(4): 321-330.

36. Chen X, Arratia G (1996) Breeding tubercles of phoxinus (teleostei: cyprinidae): morphology, distribution, and phylogenetic. implications J Morphol 228: 127-144.
37. Kortet R, Vainikka A, Rantala MJ, Jokinen I, Taskinen J, et al. (2003) Sexual ornamentation, androgens and papillomatosis in male roach (Rutilus rutilus). Evol Ecol Res 5: 411-419.

38. Kortet R, Taskinen J, Vainikka A, Ylonen H (2004) Breeding Tubercles, Papillomatosis and Dominance Behaviour of Male Roach (Rutilus rutilus) During the Spawning Period. Ethology 110: 591-601.

39. Branson BA (1962) Observations on the distribution of nuptial tubercles in some catostomid fishes. Trans Kansas Acad Sci 64(4): 360-372.

40. Thys VDA, Dirk FE (1961) Existence de deux races geographiques distinctes chez Phractolaemus ansorgei Blgr.1901 (Pisces, Clupeiformes). Bull Acad Roy Sci Outre-Mer 7(2): 222-251.

41. McGuire WR (1993) Relationships of epidermal morphology and breeding behaviors in pebble nest-building minnows (Pisces: Cyprinidae), Master's Theses University of Richmond, USA.

42. Alexander PF, Hudson RF, Earland C (1963) Wool: its chemistry and physics. Chapman and Hall, London, England.

\section{Your next submission with Juniper Publishers} will reach you the below assets

- Quality Editorial service

- Swift Peer Review

- Reprints availability

- E-prints Service

- Manuscript Podcast for convenient understanding

- Global attainment for your research

- Manuscript accessibility in different formats

( Pdf, E-pub, Full Text, Audio)

- Unceasing customer service

Track the below URL for one-step submission https://juniperpublishers.com/online-submission.php 